\title{
The Relationship between Core Competence and Self-Efficacy for Qualitative Improvement of Industrial Technology Training
}

\author{
LiHua Cui ${ }^{1}$, HyeJeong $\mathrm{Kim}^{2}{ }^{*}$ and ${\mathrm{De} \mathrm{Li}^{3}}^{3}$ \\ ${ }^{1}$ College of Economics and Management, Yanbian University, Yanji, China \\ ${ }^{2}$ Department of School of Business Administration, Kyonggi University, Seoul, Korea \\ ${ }^{3}$ Department of Computer Science, Yanbian University, Yanji, China \\ 12732677@163.com,2hj5417@naver.com, ${ }^{3}$ leader1223@ybu.edu.cn
}

\begin{abstract}
The present study aims to investigate what factors should be considered first for the development of core competencies required in businesses and measure the satisfaction and self-efficacy of learners through project-participating classes, from their view. This study measured reliability and conducted a validity analysis, based on the core competencies proposed by the OECD's DeSeCo project and the questionnaire items developed by the Korean Educational Development Institute (KEDI). The primary objectives of this study are to help students understand their subjects via project-participating classes improve their participation through an analysis of on-site practical cases and quickly adapt to their jobs in vocational training fields. For those purposes, a questionnaire survey was conducted from September 2011 until December of the same year. The project-participating classes which made use of knowledge in major fields of study to undergraduate senior students $(n=171)$ who signed contracts with industrial cooperative organizations (for the year of 2011). This study included a limited number of participants, and this small same size makes it difficult to generalize its findings.
\end{abstract}

Keywords: Core Competence, Satisfaction, Self-Efficacy, learning and learners' capabilities, project-participating classes

\section{Introduction}

In the era of knowledge and information, the most valuable resource of a company is its employees who possess technical and intellectual assets being the demands of these times. Therefore, companies make efforts to develop and train human resources for their own enterprise systems and use them for the job development through business/industrial training programs. Since these efforts are not easy to accomplish within a given amount of time in the course of vocational training, the use of knowledge and information technology related to major fields of the study should be covered during the undergraduate course and the workrelated hands-on learning programs should be considered importantly, especially in terms of availability. In particular, team-based learning by the project participation can be readily applied to on-the-job work experiences and helps improve interpersonal communication skills; thus it ensures high efficiency in the aspects of participants' satisfaction and efficacy. This paper examines what factors are needed to achieve core competencies and discusses how they can be readily applied to industrial training based on the knowledge of undergraduate majors.

\footnotetext{
* Corresponding author: HyeJeong Kim
} 


\section{Theoretical Backgrounds}

\subsection{Reform of School Education by Techno-structural Interventions}

In an ever-changing society, every organization can't seek its survival and prosperity without parallel changes. The case is same for schools, and therefore they attempt to make educational changes as independent organizations. Actually there are many different strategies for making changes to school education, but Business Administration courses require an analysis of business needs and job analysis targeting companies.

The reform of school education based on techno-structural interventions involves the efforts to make changes and improvements (Cummings \& Worley, 2004; French, Bell, \& Zawacki, 2003; Owens, 2001). However, those efforts for reform of school education seem to place emphasis on limited characteristics of school organizations. The techno-structural dimensions of businesses should be considered together when schools attempt to make changes in their organizational structures and curricula for students, including curriculum design and development.

\subsection{Core Competencies required in Industrial Technology Training}

The concept of competency was used first by White (1959) to describe individual personality in the aspect of human motivation.

McClelland (1973) argued that measurements should be concentrated on the characteristics of high performers rather than the intelligence influenced by socioeconomic factors. Since then, competencies have been deemed as capabilities needed for successful job performance in the field of vocational training and there have been competency modeling techniques developed to analyze the competencies

The existing Industrial Technology Training has been provided via uniform standardized services by reason of its structural system, rather than based on the individual needs of students as its main consumers, and in general the university education has been designed with more focus on its suppliers represented by professors than its consumers represented by students.

It is important to understand that the forms of Industrial Technology Training as education services are interactive activities which lead to the development of competencies and capabilities as their ultimate goals because the interaction between professors (or service suppliers) and students (or service consumers) is at the core of Industrial Technology Training.

\subsection{Goal-based Learning and Learners' Capabilities}

Satisfaction and Self-efficacy

Learners with high-level achievement goals tend to put more weight on their capabilities rather than on their hard work and avoid academic challenges showing emotionally negative attitudes when they are faced with failure or difficulty in their studies (Myeong-suk Kim, 2009)

Elliot and Church (1997) suggested that competence expectancy comes from the predisposing factors of achievement goal orientation in addition to the achievement motivation or the fear of failure.

Academic self-efficacy means a learner's personal judgment of his/her own ability to organize and execute the necessary courses of action for the performance of academic tasks (Ah-yeong Kim and In-yeong Park, 2001). Self-efficacy is a set of beliefs in one's capabilities which is different from individuals' expectancy about the outcome of their behavior and thus 
means the knowledge of what to do to get their desired outcome. However, learners' performance capability is measured as a performance level for goal or task achievement and their satisfaction and efficacy are derived from having a direct influence on performance as the levels of effort become higher (Kwang-hyun Han, 2005).

The history of self-efficacy begins within Bandura's (1977) social cognitive theory. The self-efficacy is a psychological attribute associated with individual learners' belief that they are able to organize and implement a series of courses required to produce a specific achievement (Bandura, 1978). Beatty et al. (1988) found that individual employees had higher levels of satisfaction when they performed their duties in an active manner. A review of empirical literature found that job satisfaction was higher in groups who placed the emphasis on teamwork (Ho-jeong Kim, 2002), and there was a report that a variety of learning strategies had a positive influence on the promotion of self-efficacy (Jong-sam Lee, 1995)

\subsection{Project Research Organization}

Technology projects to pursue research institutions activate members of the organization through interactions to occur more organically necessity to achieve the purpose of pursuing the organizational structure.

It refers to the systematic operation that the project research organization operates effectively to achieve the objectives pursued by the organization for the project.

Research organizations to perform work without a hitch, to achieve the purpose of the organization, creating a systematic study it is important to operate.

Projects within the organization, although individuals are granted the authority of a member in the organization based on individual ability and learning ability, is equipped with a considerable degree of personal influence.

This behavior in terms of their personal qualities and abilities is linked to the performance of research organizations. This linkage of the project organization can maximize operational efficiency. In particular, the agency having the technical characteristics is more important.

\subsection{Project Organization and Efficacy Study}

For researchers to focus on a particular subject and the interaction between the members in the organization through the joint to achieve the research goals. Both technical characteristics and sharing of knowledge in the course of the project will be able to acquire. Performing the project work in the inner thoughts of the researchers are in the process of synchronizing behavioral learning theory in order to perform the activities necessary to reach the target tissue, and their own ability to perform is defined as a judgment on. (Bandura; 1977) Performing technical tasks requiring the research organization by the researchers are unsure about the beliefs and expectations of self-satisfaction means.

Self-satisfaction is large or if a lot of their motivated efforts become even higher performance. Efficacy, of course, suit to perform the duties should have a real advantage there should be various constraints that are Efficacy is enhanced by information and business training to perform challenging tasks is pushing through. (Bandura, A. Ross, D., \& Ross, S. A: 1961) 


\section{Results and Discussion}

\subsection{Measured Variables}

The present study defined the OECD's DeSeCo project competencies which are well known to have been introduced from business training (or vocational training) to school education. In the field of vocational training, a competency is commonly measured in terms of technology and knowledge, but this study focused on individuals' learning attitudes or motivation in view of data characteristics. The study consulted the KEDI's research paper on "life skills" as basic capabilities supplementing personal values or emotions (Anna Kim et al., 2002, 2003 Hyeon-suk Yoo et al., 2002, 2004). The paper has significance in that it covers situational characteristics and phased key competencies. Bandura's (1978) concepts of selfefficacy and satisfaction start with a discussion of learner-centered motivation. This study should emphasize that when learners have the feelings of personal satisfaction and selfefficacy, they are likely to feel the importance of courses for their majors and the indirect effects of work-based learning and will be more motivated to study.

\subsection{Reliability Analysis}

The reliability analysis assessed measured variables using the traditional Cronbach's alpha procedure. The measured variables were found to be reliable by showing Cronbach's alpha values of more than 0.6 .

Table 1. Construct Reliability

\begin{tabular}{|c|c|c|c|}
\hline \multirow{2}{*}{ Construct } & \multicolumn{2}{|c|}{ Measured Variable } & Cronbach's alpha \\
\hline \multirow{3}{*}{ Project Competency } & OD_T1 & $\begin{array}{c}\text { Usage of relevant techniques or } \\
\text { tools }\end{array}$ & 0.848 \\
\cline { 2 - 4 } & OD_G & $\begin{array}{c}\text { Degree of interaction in } \\
\text { heterogeneous groups }\end{array}$ & 0.715 \\
\hline \multirow{2}{*}{ Life Skills } & LS_K & $\begin{array}{c}\text { Knowledge in a major field of } \\
\text { study }\end{array}$ & 0.776 \\
\cline { 2 - 4 } & LS_C & Communication skills & 0.815 \\
\cline { 2 - 4 } & PS & Problem-solving skills & 0.835 \\
\hline \multirow{2}{*}{ Efficacy } & Co & Cooperation skills & 0.632 \\
\cline { 2 - 4 } & S & Satisfaction & 0.728 \\
\hline
\end{tabular}


Table 2. Survey Items on Measured Variables

\begin{tabular}{|c|c|c|c|c|}
\hline \multicolumn{2}{|c|}{ Construct } & Reference Point & Core Competency/Ability & References \\
\hline \multirow{6}{*}{\multicolumn{2}{|c|}{$\begin{array}{l}\text { Project } \\
\text { Competen } \\
\text { cy }\end{array}$}} & \multirow{3}{*}{$\begin{array}{l}\text { Usage of } \\
\text { relevant } \\
\text { techniques or } \\
\text { tools }(\mathrm{T})\end{array}$} & $\begin{array}{c}\text { [OD_T1] Ability to use the primary language } \\
\text { or symbolic texts in courses for a major }\end{array}$ & \multirow{6}{*}{$\begin{array}{c}\text { OECD } \\
\operatorname{DeSeCo}(2005)\end{array}$} \\
\hline & & & $\begin{array}{c}\text { [OD_T2] Ability to use relevant information } \\
\text { (e.g., business cases) based on knowledge in } \\
\text { a major field of study }\end{array}$ & \\
\hline & & & $\begin{array}{c}\text { [OD_T3] Ability to use technology in an } \\
\text { interactive manner }\end{array}$ & \\
\hline & & \multirow{3}{*}{$\begin{array}{c}\text { Degree of } \\
\text { interaction in } \\
\text { heterogeneous } \\
\text { groups }(\mathrm{G})\end{array}$} & $\begin{array}{c}\text { [OD_G1] Ability to build relationships with } \\
\text { others }\end{array}$ & \\
\hline & & & $\begin{array}{l}\text { [OD_G2] Ability to work and cooperate as a } \\
\text { team member }\end{array}$ & \\
\hline & & & $\begin{array}{l}\text { [OD_G3] Ability to resolve conflicts and } \\
\text { solve problems }\end{array}$ & \\
\hline \multirow{9}{*}{$\begin{array}{l}\text { Core } \\
\text { Competen } \\
\text { ce }\end{array}$} & \multirow{9}{*}{$\begin{array}{l}\text { Life Skills } \\
\text { (ability) }\end{array}$} & \multirow{2}{*}{$\begin{array}{l}\text { Knowledge }(\mathrm{K}) \\
\text { in a major field } \\
\text { of study }\end{array}$} & $\begin{array}{l}\text { [LS_K1] Team members' theoretical basic } \\
\text { knowledge in their major field of study }\end{array}$ & \multirow{9}{*}{$\begin{array}{c}\text { Ahn-na Kim, } \\
\text { Byeong-sik Lee, Su- } \\
\text { myeong Chang and } \\
\text { Nam-ki Park (2002) } \\
\text { Ahn-na Kim, Nam- } \\
\text { hee Kim, Tae-jun } \\
\text { Kim, Seok-jae Lee } \\
\text { and Hee-ok Chung } \\
\text { (2003) } \\
\text { Hyeon-suk Yoo, Tae } \\
\text { jun Kim, Seok-jae } \\
\text { Lee and Seon-yeong } \\
\text { Song (2004). }\end{array}$} \\
\hline & & & $\begin{array}{l}\text { [LS_K2] Team members' practical } \\
\text { application of knowledge in their major field } \\
\text { of study }\end{array}$ & \\
\hline & & \multirow{3}{*}{$\begin{array}{l}\text { Communication } \\
\text { (C) skills }\end{array}$} & $\begin{array}{l}\text { [LS_C1] Ability to listen to team members } \\
\text { and gather their opinions }\end{array}$ & \\
\hline & & & [LS_C2] Ability to express oneself actively & \\
\hline & & & $\begin{array}{c}\text { [LS_C3] Team members' ability to } \\
\text { communicate matters of their interest to each } \\
\text { other }\end{array}$ & \\
\hline & & \multirow{3}{*}{$\begin{array}{l}\text { Problem-solving } \\
\text { (PS) skills }\end{array}$} & $\begin{array}{l}\text { [PS_1] Ability to diagnose and analyze the } \\
\text { causes of a problem }\end{array}$ & \\
\hline & & & $\begin{array}{l}\text { [PS_2] Ability to make decisions in an } \\
\text { efficient and timely manner }\end{array}$ & \\
\hline & & & [PS_3] Ability to overcome obstacles & \\
\hline & & $\begin{array}{l}\text { Cooperation } \\
\text { (Co) skills }\end{array}$ & $\begin{array}{c}\text { [Co_1] Ability to exchange views and reach } \\
\text { agreements }\end{array}$ & \\
\hline
\end{tabular}




\begin{tabular}{|l|l|c|c|}
\hline \multirow{2}{*}{ Efficacy } & $\begin{array}{r}\text { [Co_2] Degrees of support for and confidence } \\
\text { in others }\end{array}$ & \\
\cline { 3 - 4 } & Satisfaction & $\begin{array}{c}\text { [Co_3] Degree of respect for different } \\
\text { opinions and suggestions }\end{array}$ & \\
\hline & [S_1] I'm proud of being part of this team. & $\begin{array}{c}\text { Gist and Mitchell } \\
\text { (1992); Jong-sam Lee } \\
\text { (1995); Bandura } \\
\text { (1998); Shunk } \\
\text { (2000); Ah-yeong } \\
\text { Kim, In-yeong Park } \\
\text { (2001); Kwang-hyun } \\
\text { Han (2005); Yeong-ja } \\
\text { Ha (2005); Myeong- } \\
\text { suk Kim (2009) }\end{array}$ \\
\hline
\end{tabular}

\subsection{Multiple Regression Analysis}

Table 3 shows the results of a multiple regression analysis conducted to examine the relationship between learners' self-efficacy and performance levels in key project competencies or life skills.

As indicated in Table 3, the regression model had an explanatory power of $R^{2}=.284$, or 28.4 percent for the sample regression line, with a value of $\mathrm{F}=10.713$.

As for the relationships between independent variables on dependent variables, the communication and problem-solving skills had statistically significant effects on selfefficacy, while it was partially influenced by the usage of relevant techniques/tools and the degree of interaction of heterogeneous groups. However, the degree of knowledge in a major field of study and the cooperation skills were found to produce no significant effect.

Table 3. Results of Multiple Regression Analysis

\begin{tabular}{|c|c|c|c|c|}
\hline Construct & Measured Variable & $\beta$ & $\mathrm{t}$ & P-value \\
\hline OD_T1 & $\begin{array}{c}\text { Usage of relevant } \\
\text { techniques/tools }\end{array}$ & -0.155 & -2.306 & 0.022 \\
\hline OD_G & $\begin{array}{c}\text { Degree of interaction in } \\
\text { heterogeneous groups }\end{array}$ & 0.192 & 2.649 & 0.009 \\
\hline LS_K & $\begin{array}{c}\text { Knowledge in a major field of } \\
\text { study }\end{array}$ & -0.036 & -0.469 & 0.640 \\
\hline LS_C & Communication skills & 0.305 & 3.888 & 0.000 \\
\hline PS & Problem-solving skills & 0.209 & 3.016 & 0.003 \\
\hline Co & Cooperation skills & 0.058 & 0.774 & 0.440 \\
\hline $\begin{array}{l}\mathrm{R}^{2}=.284 \\
\mathrm{~F}=10.713^{* * *} \\
* \mathrm{p}<.05 * * * \mathrm{p}<.001\end{array}$ & & & \\
\hline
\end{tabular}




\section{Conclusion}

The present study created survey items based on the core competencies proposed by the OECD's DeSeCo project. We conducted a questionnaire survey of undergraduate students in the College of Business Administration. It was a project survey centered on industrial settings and excluded the "acting autonomously" items (ability to act from a broad perspective ability to develop and implement a plan for life and personal tasks and ability to defend/assert management, interest, limitations or claims. In addition, the questionnaire items proposed in the KEDI's study of life skills - thinking skills, self-initiated learning skills and leadershipwere excluded because of differences in given learning conditions.

As a result, the questionnaire included only the items of learner-centered satisfaction and self-efficacy because it was difficult to get project results during the semester. Businesses today organize and run high-performance teams in order to achieve short-term performance targets/results on a project basis. By paying attention to such a trend, this study attempted to measure the effects of team-based learning through a combination of theory-oriented school classes and work-based learning. Future studies need to create a new set of appropriate questionnaire items for learning or training programs so that their results can be generalized to models for qualitative changes in school organizations.

\section{Acknowledgements}

Project supported by the Humanities and Social Science Foundation of Yanbian University (Grant No. 201317).

\section{References}

[1] M.-suk Kim, "Effects of Self-Efficacy, Achievement Goal Orientation and Teacher-Perceived Emphasis on Achievement Goals on Mathematics Anxiety", Asian Journal of Education, vol. 10, no. 2, (2009), pp. 103133.

[2] A.-Y. Kim and I.-Y. Park, "Development of a Measure of Academic Self-Efficacy and Its Validity", Journal of Educational Research, vol. 39, no. 1, (2001), pp. 95-123.

[3] A.-N. Kim, B.-S. Lee, S.-M. Chang and N.-K. Park, "Qualitative Control of Higher-Education Systems for Development of Life Skills", Korean Educational Development Institute, (2002).

[4] A.-N. Kim, N.-H. Kim, T.-J. Kim, S.-J. Lee and H.-O. Chung, "Setting of National-Level Life Skill Standards and Qualitative Control of Learning Systems II", Korean Educational Development Institute, (2003).

[5] H.-J. Kim, "Effects of Korean Organizational Culture on Organizational Commitment and Job Satisfaction", Journal of the Korea Association for Public Administration, vol. 36, no. 4, (2002), pp. 87-105.

[6] J.-S. Lee, "Effects of Learning Strategy Training on Learning-Disabled Students' Mathematics Achievement, Self-Regulation, Impulsivity and Self-Efficacy”, Journal of Educational Research, vol. 33, no. 3, (1995), pp. 179-205.

[7] H.-S. Yoo, T.-J. Kim, S.-J. Lee and S.-Y. Song, "Setting of National-Level Life Skill Standards and Qualitative Control of Learning Systems III", Korean Educational Development Institute, (2004).

[8] Y.-J. Ha, "Effects of Self-efficacy and Self-regulated Learning Capability in Online Job Training for Government Employees", e-Learning Research, vol. 4, no. 1, (2005), pp. 31-63.

[9] K.-H. Han, "The Moderating Effects of Self-Efficacy on the Relationships between the Employees' Dispositional Traits and Job Burnout", Journal of the Korean Academic Society of Business Administration, vol. 18, no. 2, (2005), pp. 531-555.

[10] A. Bandura, D. Ross and S. A. Ross, "Transmission of aggression through the imitation of aggressive models", Journal of Abnormal and Social Psychology, vol. 63, (1961), pp. 575-582.

[11] A. Bandura, "Social Learning Theory", Englewood Cliffs, NJ: Prentice Hall, (1977).

[12] A. Bandura, Editor, "Self-efficacy: The Exercise of Control", New York, Freeman, (1978).

[13] S. E. Beatty, Editor, P. Homer and L. R. Kahle, "The involvement committment model: theory and implication", Journal of Business Research, vol. 16, (1988), pp. 149-167.

[14] T. G. Cummings and C. G. Worley, Organization Development and Change(8th ed.). South Western: Thomson, (2004). 
[15] DeSeCo, "The Definition and selection of key competencies; executive summary", Retrieved, (2005) October 25.

[16] A. J. Elliot and M. A. Church, "A Hierarchical Model of Approach\& Avoidance Achievement Motivation", Journal of Personality and Social Psychology, vol. 72, no. 1, (1997), pp. 218-232.

[17] W. French, C. H. Bell and R. A. Zawacki, Organizational Development and Transformation(6th Ed.).Boston: MacGraw-Hill, (2003).

\section{Authors}

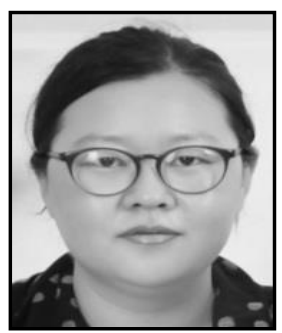

LiHua Cui received the Ph.D. degree from KookMin University, major in Financial Management in 2008. She is currently a professor of Dept. of Financial Management at Yanbian University in China. She research interests are in the areas of business finance, value assessment, merger and acquisition, Engaged in financial analysis.

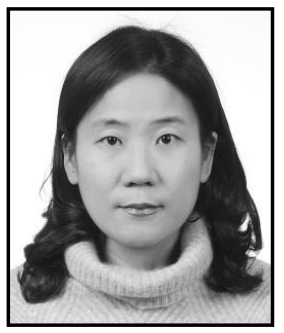

Hye Jeong Kim received the Ph.D. degree from KookMin University, major in Business Administration in 2006. She is currently a professor of Dept. of Operations Management at Kyonggi University in Korea. She is also a Principal Researcher at Institute, Human Resource Development Institute of Korea. She research interests are in the areas of Technology and Engineering, Production /Operations Management, Quality Management.

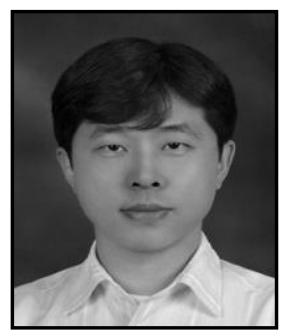

De $\mathbf{L i}$ received the Ph.D. degree from Sangmyung University, major in computer science in 2005. He is currently a professor of Dept. of Computer Science at Yanbian University in China. His research interests are in the areas of Technology and Engineering, value assessment, financial analysis, copyright protection, digital rights management. 